\title{
Kriz Yönetimine İlişkin Bilimsel Eğilimlerin Resmedilmesi: Lisansüstü Tezlerin Analizi
}

\author{
Sibel Hoştut (Doç. Dr.) \\ Akdeniz Üniversitesi İletişim Fakültesi \\ shostut@akdeniz.edu.tr \\ Orcid: 0000-0002-5372-1499
}

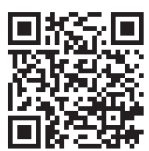

Başvuru Tarihi: 19.07.2018

Yayına Kabul Tarihi: 11.12.2018

Yayınlanma Tarihi: 21.01.2019

\section{Öz}

Yapılan çalışmanın amacı, 1992-2017 yılları arasında Türkiye'de yazılan kriz yönetimi araștırmalarının bibliyometrik özelliklerini açıklayarak alana ilişkin genel eğilimlerin resmedilmesi ve akademik birikiminin ortaya konmasıdır. Bunun için "Kriz Yönetimi” anahtar kelimesini lisansüstü tez başlığında içeren 161 yüksek lisans ve doktora tezleri içerik analizi tekniğiyle incelenmiştir. Tezlerdeki niceliksel artış, araştırma konularındaki çeşitlilikle paralellik göstermektedir. Çalışmada, 25 araştırma konusu açıklanmıştır. Ancak işletme konulu tezlerin sayıca çokluğu söz konusudur. Konuların çeşitliliğine paralel olarak kullanılan anahtar kelimeler de çeşitlilik göstermektedir. Toplam 185 farklı anahtar kelime kullanılmış ve ortalama kullanılan anahtar kelime sayısı beștir. "Kriz Yönetimi" en sık kullanılan birinci kelime iken, "Kriz" kavramı en sık kullanılan ikinci kelime olmuştur. Kullanılan diğer 183 anahtar kelime ise, farklı disiplinlerde çalışılan tez konularındaki çeşitlilik ile yakından ilgilidir. Tezlerde atıf yapılan bilimsel kaynak türlerinin ilk üç sırası özellikle işletme yönetimi ve kriz yönetimine ilişkin Türkçe yazılmış kitap, makale ve tezlerden oluşmaktadır. Bu durum Türkçe yazınında kalıcı ve klasik çalışmaların varlığını ve kriz yönetimi literatürüne katkıda bulunan Türk yazarların oldukça fazla olduğunu göstermektedir. Ancak kriz yönetimine ilişkin spesifik dergilerin en sık atıf alanlar arasında bulgulanmaması üzerinde durulması gereken konuların başında gelmektedir.

Anahtar Kelimeler: Kriz Yönetimi, Bibliyometrik Analiz, İçerik Analizi, Lisansüstü Tezi.

\footnotetext{
* Bu çalışma, 25-26 Kasım 2017 tarihinde Antalya'da düzenlenen Uluslararası Multidisipliner Çalışmaları Kongresinde "Kriz Yönetimi Çalışmaları" başlığıyla sunulan bildirinin genişletilmiş halidir.
} 


\title{
Representing Scientific Trends In Crisis Management: Analysis of Master and Doctoral Theses
}

\author{
Sibel Hoştut (Assoc. Prof. Dr.) \\ Akdeniz University Faculty of Communication \\ shostut@akdeniz.edu.tr \\ Orcid: 0000-0002-5372-1499
}

Date Received: 19.07.2018

Date Accepted: 11.12.2018

Date Published: 21.01.2019

\section{Abstract}

The aim of this investigation is to highlight the bibliometric features of crisis management research in Turkey to demonstrate the academic background and to provide a clear picture of the field. For this, 161 master and doctoral theses written from 1992 to 2017, and with the keyword "crises communication" in their titles were analyzed by using content analysis technique. The quantitative increase of the theses is in line with the diversity of research subjects. In this study, 25 research topics are explained. However, there is a large number of theses related to business issues. The used keywords also vary in parallel with the variety of subjects. A total of 185 different keywords have been used and the average number of used keywords is five. "Crisis Management" and "Crisis" have been the most commonly used keywords. The other 183 keywords are closely related to the diversity of the thesis topics studied in different disciplines. The first three ranks of scientific sources consist of books, articles, and theses written in Turkish, especially in the field of business and crises management. This situation shows a quite high existence of Turkish writers who contribute to the business and crisis management literature with permanent and classical studies. However, the fact that specific journals related to crisis management are not found among the most frequently cited subjects is one of the issues that have to be considered.

Keywords: Crisis Management, Bibliometric Analysis, Content Analysis, Master and Doctoral Theses. 


\section{Giriş}

İlgili alan yazınında kriz olgusuyla ilgili çok sayıda tanım mevcuttur. Kriz; bir grubu, takımı veya bir organizasyonu aşağı yönlü bir sarmal içine alan herhangi bir durum ya da olay dizisidir ve etkin bir șekilde ele alınmazsa insanlara, organizasyona, paydaşlara, hatta tüm bir endüstriyi olumsuz etkileyebilir veya zarar verebilir (Hale ve diğerleri, 2005). Bu olumsuz etkiler; kamu güvenliği, operasyonların aksamasından kaynaklanan mali, pazar payı ile itibar kaybı gibi birbiriyle ilişkili tehditler olușturur (Coombs, 2014). Akdağ $(2001,34)$ ise geniş kapsamlı bir tanım yaparak krizi; beklenmedik, aniden gelişen, hızlı hareket eden, herhangi bir hazırlık yapılmadan karşı karşıya kalınan veya belirtileri önceden olduğu halde fark edilmeyen ve örgüt için iyi değerlendirilmezse çöküş, iyi değerlendirilirse fırsat anlamına gelebilecek bir durum olarak tanımlamaktadır. Kurumların karşılaşabilecekleri kriz türleri birbirinden çok farklı olabilir. Burada Mitroff ve diğerleri $(1987,287)$ kurumsal krizleri türlerine göre tanımlayabilmek için krizlerin teknik/ekonomik, dahili, harici ve insan/toplumsal/örgütsel sınıflandırmasını yapmışlardır. Yapılan sınıflandırma, kurum faaliyetlerinin ve performansının etkilenebileceği krizlerle ilgili büyük resmin görülmesini, ilgili planlamalar yapılarak önlemlerin alınmasını sağlamaktadır.

Kriz, tüm dünyada olduğu gibi Türkiye'de de özellikle 1980'li yıllardan sonra kendisini daha fazla göstermeye başlamış ve küreselleşme ile bu etkileşim daha da hızlanmıştır (Soysal ve diğerleri, 2009, 432). Türkiye'de 1982 bankerler krizi, 1994, 1998 ve 2001 ekonomik krizleri ve 1999 Marmara depremi başlıca krizler olarak tanımlanırken, 1990 Körfez Savaşı krizi, 1997 Asya krizi, 1998 Rusya krizi, 1999 Brezilya krizi, 2001 Arjantin ekonomik krizi, 2008 dünya finans krizi ve 2014 Rus finans krizi küresel arenada yaşanan önemli krizler olarak ifade edilmektedir. Makro ve mikro ortamda yaşanan çeşitli krizler, farklı disiplinlerde kriz yönetimi konusunun çalışılmasına, kitapların ve makalelerin yayımlanmasına, konferansların düzenlenmesine, spesifik dergilerin yayımlanmasına ve lisansüstü çalışmaların yapılmasına neden olmuştur. Bu çalışmalarda kriz türleri, yönetim planları, stratejileri, taktikleri ve iletişimi hem kuramsal hem de vaka çalışmalarıyla ilişkilendirilerek incelenmiştir. Türkiye'de de son 25 yılda çok sayıda makaleler ve kitaplar yazılarak, konferans sunumları yapılarak, yüksek lisans ve doktora tezleri yazılarak kriz yönetimi literatürüne ve alanın gelişmesine katkıda bulunulmuştur. Yapılan çalışmanın amacı, 1992 - 2017 yılları arasında kriz yönetimi başlığını içeren yüksek lisans ve doktora tezlerini irdeleyerek (tezlerin yazıldıkları yıllar, sayfa sayıları, üniversiteler ve enstitüler, araştırma konuları, özgün dilleri, atıf yapılan temel kaynaklar) alana ilişkin genel eğilimlerin resmini çizmek ve kriz yönetimi literatürüne katkı sağlamaktır. Çalışmadaki zaman aralığının 1992-2017 olarak belirlenmesindeki amaç, ilk yüksek lisans tezinin 1992 yılında yazılmış olmasından son yapılan çalışmalara kadar geçen süredeki eğilimleri açıklamaktır.

\section{Meta Analizi Çalışmaları}

Disiplinlerin gelişmesinde tezlerin çok önemli bir fonksiyonu vardır. Tezler, geçerlik ve güvenirliği sağlanmış araştırmalar olmanın yanı sıra bilimsel bir jüri önünde savunulma, belirli zamanlarda metodolojik ve tematik eğilimleri gösterme gibi özellikleri ile ilgili alanın gelişim seyrini bilimsel bir düzlemde ortaya koyabilmektedir (Şenyurt ve Özkan, 2017, 631). Ulusal Tez Merkezi arşivinde bulunan tezlerin tamamı, "Elektronik Tez Arşiv Projesi" ile sayısal ortama taşınmış ve yazarları tarafından "çoğaltması ve yayımı için" izin verilmiş olanlar tam metin (pdf) olarak 
erişime açılmıştır (YÖK Tez Merkezi, 2018). Yükseköğretim Kurulu Başkanlığı Tez Merkezinde (06.12.2018) 557.266 kayıt bulunmaktadır. Bu yüksek rakam, kişilerin lisansüstü eğitime gösterdikleri ilgiyi ve verdikleri önemi yansıtmanın yanı sıra sunulan çalışmalar ilgili bilim dallarına önemli katkılar sunmakta ve bilimin gelişmesinde önemli bir yer tutmaktadır. Bu bilgi yığınını yorumlamak ve yeni çalışmalara yol açmak için, kapsayıcı ve güvenilir nitelikte üst çalışmalara ihtiyaç vardır (Akgöz ve diğerleri, 2004, 107).

Araştırma konularının özetlenmesi veya yazarlar, kurumlar, dergiler gibi araştırma bilgilerinin istatistiksel olarak ölçülmesi için çeşitli teknikler kullanılmaktadır (Jiang ve diğerleri, 2017,3). Bilimin temeli de çok sayıda çalışmanın sonuçlarından bilgi birikiminin sağlanmasına dayanmaktadır (Çarkungöz ve Ediz, 2009, 33). Belirli bir alanda yayınlanmış çalışmaların analizi; ilgili araştırmacıların bilgi ve kanıtlanmış argümanlara olan katkılarının ifade edilmesi ve belirli bir akademik araştırma için var olan bilgi çeşitliliğinin yönetilmesi konularında kritik bir öneme sahiptir (Tranfield ve diğerleri, 2003, 208; Denyer ve Tranfield, 2006, 216). Bu çerçevede önemli bir tekniği meta analizi sunmaktadır. İlk, Glass (1976, 3) tarafından kullanılan meta analizi kavramı, aynı alanda veya konuda yapılmış çalışma sonuçlarının sentezlenmesi (Normand, 1999) ya da bir konu ya da çalışma alanı hakkında benzer çalışmaların belirli ölçütler altında gruplanıp, bu çalışmalara ait nicel bulguların birleştirilerek yorumlanması (Dinçer, 2014, 4) olarak tanımlanmaktadır. Meta analizinde, iki veya daha fazla çalışma sonuçları istatistiksel yöntemler kullanılarak birleştirilmeye çalışıldığından, sistematik bir teknik olarak ifade edilmekte (Russo, 2007, 637), sayılardan güç alması yönüyle de, nitel bir bakış açısından araştırmaları özetleyen literatür tarama çalışmalarından ayrılmaktadır (Başol ve diğerleri, 2016, 715). Russo (2007), her ne kadar meta analizini sistematik bir teknik olarak ifade etse de, Khan ve diğerlerine $(2005,2)$ göre bir meta-analizi, "sistematik bir gözden geçirme" ile aynı değildir, aksine bir gözden geçirmenin bir parçasıdır. Birkaç bireysel çalışmanın sonuçlarını tek bir genel sonuçla birleştiren istatistiksel bir süreçtir.

Halkla ilişkiler araştırmalarındaki trendlerin ve değişimlerin tespiti için 1980’li yıllardan itibaren çok sayıda meta analizleri yapılmaktadır. İlk dönem çalışmalarından Ferguson'un (1984) çalışmasında, halkla ilişkiler bilimcilerinin kuram inşası durumu araştırma konusu iken, Broom ve diğerlerinin (1989) çalışmasında kullanılan çeşitli araştırma konuları ve yaklaşımları tanımlanmaya çalışılmıştır. Morton ve Lin (1995) 1975 - 1992 yılları arasında Public Relations Review dergisinde yayınlanan çalışmaların konularını ve kullanılan araştırma yöntemlerini incelemişlerdir. Araştırmacılar, nitel çalışmaların (\% 60) nicel çalışmalardan (\% 40) daha fazla olduğunu ve mesleki konuların (lisans ve standartlar, uygulamalar ve ilkeler, kuram, eğitim, etik ve tarih) açık ara ile yönetim konularından (konular/kriz yönetimi, yasal konular, kitle analizi, araştırma) ve teknik konulardan (tanıtım, medya ilişkileri, grafik tasarım ve fotoğrafçılık) daha fazla çalışıldığını açıklamışlardır. Cutler (2004), Public Relations Review dergisinde yayınlanan örnek olay çalışmalarındaki yöntemlerin niteliğini incelemiș ve az sayıda araștırmacının iyi örnek olay yöntemini anladığını veya uyguladığını açıklamıştır.

Nitekim belli bir disiplinin akademik birikiminin ortaya çıkartılması meta analizi çalışmalarını gerekli kılmaktadır (An ve Cheng, 2010, 65). Çünkü meta analizi, bir araștırma alanındaki gelişmelerin çeșitli yönlerinin sistematik olarak 
incelenmesini mümkün kıldığı (An ve Cheng, 2010, 65) gibi gelecek araştırmalara da rehber olmaya yardımcı olmaktadır (Coombs, 2016, 122).

\section{Halkla İlişkilerde Bibliyometrik Çalışmalar İncelemesi}

Halkla ilişkiler araștırmalarında gerçekleștirilen bir diğer meta analizi türü yayınları, yazarları ve alıntıları analiz eden bibliyometrik çalıșmalar ya da atıf analizleridir (An ve Cheng, 2010, 66). Bibliyometri, belirli bir alanda ve belirli bir zaman aralığında kişiler ya da kurumlar tarafından üretilmiş yayınlar ve bu yayınlar arasındaki ilişkilerin sayısal analizi (ULAKBİM, 2018) olarak tanımlanmaktadır. Bir düşüncenin kaynağını açıklama olarak tanımlanan atıf yapmanın temel işlevleri olarak atıf yapan ile atıf yapılan belge arasında bağ kurmak, önceki araştırmaları tanıtmak ve daha geniş okuma olanağı sağlamaktır (Al ve Tonta, 2004, 21). Bilimsel literatürdeki atıflar iki şekilde karakterize edilir; yüksek atıf içeren kalıcı ve klasik makaleler ile kısa sürede zirve yapan geçici çalışmalar (Price, 1965, 149). İkincisine örnek olarak bilimsel literatürdeki yeni eğilimlerin ve ani değişikliklerin beraberinde getirdikleri yeni keşifler veya bir konunun yeni perspektiften incelemesi gösterilebilir (Chen, 2006, 359). Bibliyometrik çalışmalar, çeşitli bilim dallarına ilişkin bilimsel gelişimi ve gereksinimleri belirlediği için kritik öneme sahiptir (Yıldız ve diğerleri, 2016, 1078). Niceliksel bir yaklaşım ile yayınlanmış çalıșmanın tanımlanması, değerlendirilmesi ve izlenmesi yapılır. Çalışmanın sistematik, şeffaf ve tekrarlanabilir olması araștırmanın kalitesini olumlu yönde etkilemektedir (Zupic ve Cater, 2015, 430).

Bibliyometrik çalışmaların ilgili bilim dalına çeşitli katkıları vardır. Yapılan analizler; araştırma alanına ilişkin istatistiksel verileri, yeni eğilimleri ve konuları açıklar ve okuyuculara o spesifik konunun bir kaynakçasını sunar (Ellegaard ve Wallin, 2015). Aynı zamanda alanda çalışma yapan veya alan dışından gelen yeni araştırmacılara alanla ilgili en popüler yazarlar ve eserler hakkında bilgi sunarak (Benckendorff ve Zehrer, 2013, 125) rehberlik eder ve araștırma alanını öznel, ön yargı olmadan haritalandırarak okuyucuya büyük kolaylık sağlar (Zupic ve Cater, 2015, 430). Araştırmacılar farklı motivasyonlarla bibliyometrik araştırmalara yönelmektedir (Al ve diğerleri, 2012, 54). Belirli bir alanda en verimli araştırmacıların belirlenmesini amaç edinen ve çok kapsamlı olmayan çalışmalardan, araştırmacılar arasındaki etkileşimin nedenlerinin ortaya konulması ve açıklanması üzerine yapılan derinlemesine araştırmalara kadar birçok konu bibliyometrik tekniklerle incelenebilmektedir. Öte yandan karşılaștırma amaçlı olarak ülkelerin, kurumların ve hatta bölümlerin araştırma performanslarının çeşitli göstergeler (h-endeksi, öğretim üyesi başına düșen yayın ve atıf sayısı gibi) açısından sorgulandığı çalışmalar da mevcuttur (Al ve diğerleri, 2012, 54). Yuan ve diğerleri $(2014,417)$ bibliyometrik çalışmalar için beş başlık tanımlamıştır. Bunlar; bireysel araştırmacıların ve kurumların bilimsel performansı, bilgi akıșı ve sosyal ağlar, konuların analizi ve uzun vadeli gelişme eğilimleri, dergi sıralaması ve dergi gelişimi ve en çok alıntı yapılan yazarlar ve eserler şeklindedir.

1990’lı yıllardan itibaren halkla ilişkiler araştırmalarında bibliyometrik çalışmalar yapılmaktadır (Pasadeos ve Renfro, 1992; Pasadeos ve diğerleri, 1999). Pasadeos ve diğerleri (1999) en sık atıf alan yazarları, en sık yayın yapan yazarları, en sık kullanılan kaynak türlerini (dergi, kitap, konferans bildirisi, tezler ve medya gibi) ve en sık kullanılan kaynakları açıklamışlardır. Yapılan çalışmaya göre halkla ilişkiler literatüründe J. Grunig, D. Dozier, G.M. Broom ve L. Grunig en sık atıf alan yazarlar, en sık atıf yapılan kitap ise Grunig ve Hunt'ın (1984) Managing Public Relations 
kitabıdır. Morton ve Lin'in (1995) çalışmasında da J.Grunig en sık atıf alan yazar, Public Relations Review dergisi de açık ara ile en çok atıf yapılan dergi olarak tespit edilmiştir. Sallot ve diğerleri (2003) Ferguson'un (1984) çalışmasını yenilemişler ve Public Relations Review, Journal of Public Relations Research ve Public Relations Research Annual dergilerinde yayınlanan makaleleri incelemişlerdir. Ferguson'un (1984) yalnızca Public Relations Review'da yayınlanan makalelerin incelendiği çalışmasında güçlü kuram gelişiminin bulgulanmadığı sonucu çıkarılırken, Sallot ve diğerlerinin (2003) çalışmasında analiz edilen makalelerin yaklaşık \% 20'sinin halkla ilişkilerde kuram gelişimine katkıda bulunduğu açıklanmıştır. Bu kuramların; mükemmellik/simetri, kamu ilişkileri, etik ve sosyal sorumluluk, krize tepki, eleştirel-kültürel, feminizm/çeşitlilik ve uluslararası konuları içeren çalışmalarda daha çok bulgulandığı ifade edilmektedir. Halff ve Gregory (2014), Asya-Pasifik ülkelerinde halkla ilişkiler alanındaki ortak konuların ve kuramsal anlayışların tanımlanması için tarih yazımlarını incelemişlerdir. Yazarlar, AsyaPasifik'teki halkla ilişkilere Batılı modellerin paradigma temellerinden farklı bir tarihsel perspektif çizmişler, bu coğrafyada halkla ilişkilerin incelenmesi için gerekli bulunan bileşenlerin bir listesini önermişlerdir. Yazarlar ayrıca küreselleşen bir dünyada Batı ve Asya-Pasifik bölgesindeki halkla ilişkiler arasında epistemolojik ve uygulama farklılıklarına ilişkin sonuçlar çıkartmışlardır. Kim ve diğerleri (2014), halkla ilişkiler alanındaki belirgin anahtar kelimeleri belirlemek için 1975 - 2011 yıllarında yayınlanan Public Relations Review ve Journal of Public Relations Research dergilerinde yayınlanan çalışmaların başlıklarındaki anahtar kelimelerin analizini yapmışlardır. Çalışmada; iletişim, halkla ilişkiler, kamu, uygulayıcı ve kurum en belirgin anahtar kelimeler olarak tespit edilmiştir. Nitekim yapılan çalışmalar, halkla ilişkiler bilimcilerinin kuram gelişimine katkıları, araştırma konuları ve yaklaşımları, en sık atıf alan yazarlar, en sık yayın yapan yazarlar, en sık atıf yapılan kaynak türleri, türlere ilişkin sıralamalar ve kullanılan anahtar kelimelerin analizine odaklanmaktadır.

Uzun bir geçmişe dayanan halkla ilişkiler alanındaki bibliyometrik analizler literatüre katkı sağlarken, kriz yönetimi konusundaki çalışmalar daha yakın zamana dayanmaktadır. An ve Cheng (2010), 1975 - 2006 yılları arasında Journal of Public Relations Research and Public Relations Review dergilerinde yayınlanan kriz iletişimiyle ilgili araştırma makalelerini incelemişlerdir. Yazarlar, kriz iletişimi yayınlarında niceliksel bir artışın olduğunu, kuramsal araştırmaların ve yöntemsel uygulamaların potansiyel bir eksikliğini ve nitel yöntemlerin daha çok uygulandığını ifade etmişlerdir. Kim ve diğerleri (2009), 1991 - 2009 yılları arasında 11 farklı dergide yayınlanan 51 makalenin analizinde krizlere ilişkin yanıt stratejilerini incelemişlerdir. Çalışmada, desteklemek ve reddetmek en sık belirtilen iki strateji olarak açıklanmış, kuram ve uygulama arasındaki gediğin ve gelecek araştırmalara yönelik vurgulamaların eksikliği belirtilmiştir. Wang ve Dong (2017) çalışmalarında 2009 - 2017 yılları arasında 11 iletişim ve halkla ilişkiler dergilerinde yayınlanan sosyal medyayla ilişkili kriz iletişimi araştırmalarındaki araştırma konularını, eğilimleri ve özellikleri, kuram ve kuramsal modelleri, kriz türlerini, sosyal medya platformlarını, örneklem türlerini ve araştırma yöntemlerini incelemişlerdir. Çalışma bulguları, sosyal medyayla ilgili kriz iletişim çalışmalarının artan bir eğilime işaret ettiğini ve çalışmaların \% 75'inde kuram veya kuramsal modellerin kullanıldığını göstermektedir. 


\section{Araştırma ve Yöntem}

Yapılan çalışmanın amacı, Türkiye'deki kriz yönetimi araştırmalarının bibliyometrik özelliklerini açlklayarak alana ilişkin genel eğilimlerin resmedilmesi, bilgi tabanlarının ve akademik birikiminin ortaya konmasıdır. Bunun için Yükseköğretim Kurumu Başkanlığının Ulusal Tez Merkezinin (2017)1 veri tabanında "Kriz Yönetimi" anahtar kelimesini tez başlığında ifade eden yüksek lisans ve doktora tezleri incelenmiștir. Bu veri tabanında 1992 - 2017 yılları arsında 161 yüksek lisans ve doktora tezi bulunmaktadır. Araștırma kapsamında tezlerin bibliyometrik özellikleri (yüksek lisans ve doktora türlerine göre sayıları, araştırma konuları, yıllara göre dağılımı, yazarların cinsiyeti, tezlerin yazıldığı üniversiteler ve sayfa sayıları, atıf yapılan yazarlar ile kaynaklar ve kullanılan anahtar kelimeler) tespit edilmeye çalışılmıştır. Bunun için Excel ve SPSS programlarından faydalanılmıştır. Tezlerde atıf yapılan kaynaklar; kitap, dergi, yüksek lisans ve doktora tezleri ve diğer yayınlar kategorilerine ayrılmıştır. Atıf yapılan kitapların bazılarının kitap başlığı aynı olmasına rağmen yayın yılının farklı olduğu durumlar saptanmıştır. Değerlendirmenin sağlıklı yapılabilmesi için kitapların ilk ve sonraki yıllardaki tekrar baskılarına ilişkin yayın yıllarına yapılan atıflar birlikte değerlendirilmiștir. Araștırma konusuyla ilgili ilk yüksek lisans tezinin 1992 yılında yazılmış olması, çalışmada belirlenen zaman aralığının netleşmesinde etkin olmuştur.

İlgili çalışma kapsamında, aşağıdaki araştırma sorularına cevap aranmıştır:

- S1: Ülkemizdeki lisansüstü eğitiminde kriz yönetimi ne kadar çalışılmıştır?

- S2: Tezlerin üniversitelere ve enstitülere, yayınlandıkları yıllara, konulara ve özgün dillerine göre dağılımları nasıldır?

- S3: Tezlerde en sık atıf yapılan kaynak türü hangisidir?

- S4: Tezlerde hangi kaynaklara en sık atıf yapılmaktadır?

- S5: Yerli - Yabancı kaynak kullanımı nasıldır?

Atıf ve içerik analizleri bu tür çalışmalarda en yaygın yaklaşımlar olarak ifade edildiğinden (Yuan ve diğerleri, 2014, 417) kriz yönetimi ile ilişkilendirilen temel sorular içerik analizi tekniği ile açıklanmaya çalışılmıştır. Berelson $(1952,17)$ içerik analizini içeriğin tarafsız, sistematik ve niceliksel tanımı olarak ifade ederken, Stone ve diğerleri $(1966,213)$ metin içinde tanımlanan belirli karakterlerden sistematik ve tarafsız sonuçlar çıkarmak için kullanılan bir araştırma tekniği olarak tanımlamıştır. Yıldırım ve Şimşek'e (2005, 227-232) göre, bunun için toplanan verilerin önce kavramsallaştırılması, daha sonra da ortaya çıkan kavramların mantıklı bir biçimde düzenlenmesi ve buna göre veriyi açıklayan temaların saptanması gerekmektedir. Böylece verilerin içinde saklı olabilecek gerçeklerin ortaya çıkarılması sağlanır. Toplanan verilerin analizine rehberlik edecek bir kavramsal yapı olmadığı için, toplanan verilerin tümevarımcı bir analize tabi tutulması sonucu araştırmacı tarafından doğrudan verilerden oluşturulan bir kod listesi ortaya çıkarılır. Oluşturulan kod listesi nitel (kalitatif) verilerin düzenlenmesinde önemli bir kolaylık sağlar (Ylldırım ve Şimşek, 2005, 228).

Yapılan çalışmada araştırmacı, pdf formatında incelemiş olduğu lisansüstü tezleri anlamlı bölümlere ayırarak, isimlendirme ve kodlama işlevini yapmıştır. Hazırlanan kod listesi araştırmacı tarafından tekrar kontrol edildikten ve geliștirildikten sonra bağımsız iki akademisyenin görüşleri doğrultusunda son halini almıştır. Kodlama listesi, kodların belirli kategoriler altında sistemli bir düzende toplanmasını sağlayacak kategorilerin bulunmasını sağlamıştır. 
Araştırma kapsamında 161 tezin tamamının künye bilgilerine ulaşılmış, ancak 62 tezin pdf formatına (metnine) ulaşılamamıștır. Böylece çalışmanın en sık kullanılan kaynak türleri ve en sık kullanılan kaynaklar bölümleri tez erişiminin açık olduğu 99 tez üzerinden araştırılmıştır.

\section{Bulgular}

1992 - 2017 yıllarını kapsayan 25 yıl içinde kriz yönetimi alanında 161 tez yazılmıştır. Yazılan tezlerin \% 94'ü (151) Türkçe ve \% 6’sı (10) İngilizce dilinde yazılmıştır.

Yüksek lisans tezleri en az 66 en fazla 343 sayfa uzunluğundadır. Ortalama sayfa sayısı 148'dir. Yüksek lisans tezlerinde kullanılan kaynak sayısı en az 23 en fazla 393'tür. Ortalama kullanılan kaynak sayısı ise 70'tir. Doktora tezleri en az 136 en fazla 459 sayfa uzunluğundadır. Ortalama sayfa sayısı ise 285 'tir. Doktora tezlerinde kullanılan kaynak sayısı en az 107 en fazla 356'dır. Ortalama kullanılan kaynak sayısı ise 228 'dir.

Tezleri yazan kişilerin isimlerinin değerlendirilmesiyle cinsiyetler belirlenmeye çalışılmıştır. İsminden cinsiyeti belirlenemeyen yazarlar ise "bilinmiyor" başlığı altında toplanmıștır. Tablo 1'de tezleri yazan kișilerin cinsiyetlerine ilișkin bulgular gösterilmektedir.

Tablo 1: Tezleri Yazanların Cinsiyetleri

\begin{tabular}{|l|c|c|c|c|c|}
\hline \multirow{2}{*}{ Cinsiyet } & \multicolumn{2}{|c|}{ Yüksek Lisans } & \multicolumn{2}{c|}{ Doktora } & \multirow{2}{*}{ Toplam } \\
\cline { 2 - 5 } & Sıklık & Oran & Sıklık & Oran & \\
\hline Kadın & 60 & 43 & 8 & 40 & 68 \\
\hline Erkek & 69 & 49 & 12 & 60 & 81 \\
\hline Bilinmiyor & 12 & 8 & - & - & 12 \\
\hline Toplam & 141 & 100 & 20 & 100 & 161 \\
\hline
\end{tabular}

Tablo 1'e göre hem yüksek lisans hem de doktora tezlerinde erkeklerin oranı kadınlara göre daha fazladır. Bu durum doktora tezinde daha da belirgindir (erkekler $\%$ 60; kadınlar \% 40).

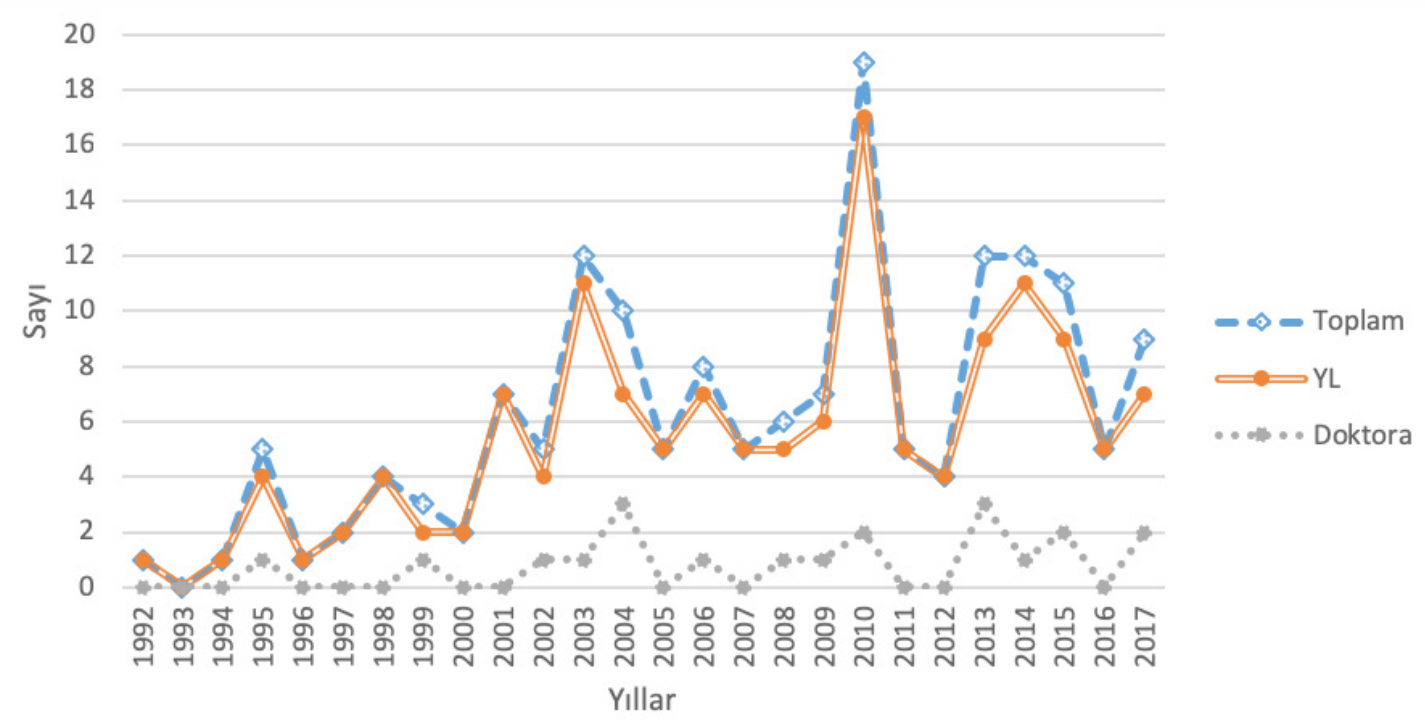

Şekil 1: Tezlerin Yıllara Göre Dağılımı

Tezler yıllara göre incelendiğinde büyük dalgalanmalar görülmektedir. 161 tezin \% 88'i yüksek lisans (141) ve \% 12'si doktora (20) tezidir. İlk yüksek lisans tezi 1992 
yılında Marmara Üniversitesi Yönetim ve Organizasyon Anabilim Dalında, ikincisi ise 1994 yılında Ege Üniversitesi Halkla İlişkiler Anabilim Dalında yazılmıștır. Salt 1993 yılında kriz yönetimiyle ilgili tez yazılmamışken, en fazla tez 2010 yılında (toplam 19 tez) yazılmıştır.

1992-2017 yılları arasında özellikle yüksek lisans tezlerinde bir süreklilik tespit edilirken, doktora tezlerinde küçük bir artış tespit edilse de, hiç yayınlanmadığı yıllar oldukça fazladır $(1992,1993,1994,1996,1997,1998,2000,2001,2005,2007,2011$, 2012, 2016). İlk doktora tezi 1995 yılında Selçuk Üniversitesi İşletme Bölümünde, ikincisi 1999 yılında Anadolu Üniversitesi İşletme Bölümünde ve üçüncüsü de 2002 yılında İstanbul Üniversitesi Kamu Yönetimi Bölümünde yazılmıştır.

Tezlerin yazıldıkları üniversitelere göre dağılımı tablo 2'de gösterilmektedir.

Tablo 2: Tezlerin Üniversitelere Göre Dağılımı

\begin{tabular}{|l|l|c|c|c|c|}
\hline Sıra & Üniversite & Tür & Yüksek Lisans Tezi & Doktora Tezi & Toplam \\
\hline 1 & Marmara Üniversitesi & Devlet & 17 & 3 & 20 \\
\hline 2 & Gazi Üniversitesi & Devlet & 10 & - & 10 \\
\hline 3 & Selçuk Üniversitesi & Devlet & 7 & 2 & 9 \\
\hline 4 & Dokuz Eylül Üniversitesi & Devlet & 6 & 2 & 8 \\
\hline 5 & İstanbul Üniversitesi & Devlet & 4 & 4 & 8 \\
\hline 6 & Yıldız Teknik Üniversitesi & Devlet & 7 & - & 7 \\
\hline 7 & Anadolu Üniversitesi & Devlet & 4 & 2 & 6 \\
\hline 8 & Kocaeli Üniversitesi & Devlet & 6 & - & 6 \\
\hline 9 & Dumlupınar Üniversitesi & Devlet & 5 & - & 5 \\
\hline 10 & Haliç Üniversitesi & Vakıf & 5 & - & 5 \\
\hline & Toplam & & 71 & 13 & 84 \\
\hline
\end{tabular}

54 Üniversitede yazılan 161 yüksek lisans ve doktora tezlerinin \% 52'si tablo 2'de gösterilen üniversitelerde yazılmıştır. $\mathrm{Bu}$ üniversiteler sıralandığında, en fazla tezlerin Marmara Üniversitesi, Gazi Üniversitesi, Selçuk Üniversitesi, Dokuz Eylül Üniversitesi, İstanbul Üniversitesi, Yıldız Teknik Üniversitesi, Anadolu Üniversitesi, Kocaeli Üniversitesi, Dumlupınar Üniversitesi ve Haliç Üniversitesinde yazıldıkları görülmektedir. Tezler yüksek lisans ve doktora özelinde incelendiğinde en fazla yüksek lisans tezleri Marmara Üniversitesi ve Gazi Üniversitesi, doktora tezleri ise İstanbul Üniversitesi ve Marmara Üniversitesi'nde yazılmıştır. Tablo 3'te 25 yıldır yazılmakta olan yüksek lisans ve doktora tezlerinin araştırma konularına göre sınıflandırılmaları gösterilmektedir. 
Tablo 3: Kriz Yönetimiyle İlgili Tezlerin Araştırma Konuları

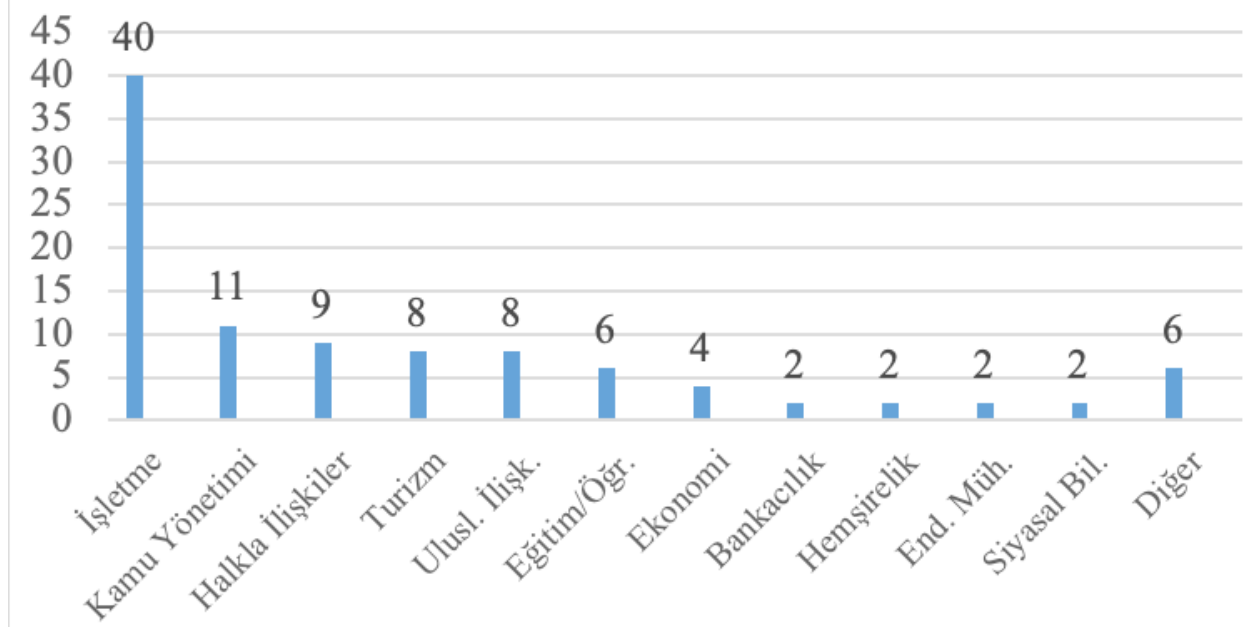

Tezlerin temel konuları işletme, kamu yönetimi, halkla ilişkiler, turizm, uluslararası ilişkiler, eğitim/öğretim, ekonomi, bankacılık, hemşirelik, endüstri mühendisliği, siyasal bilgiler gibi 25 farklı disipline işaret etse de, işletme konulu tezlerin (\% 40) çokluğu dikkat çekmektedir. "Diğer" kategorisi içerisinde yer alan konular ise bilgisayar mühendisliği, inşaat mühendisliği, denizcilik, dilbilim, din, iletişim bilimleri, gazetecilik, hastaneler, jeodezi ve fotogrametri, kazalar, sağlık kurumları yönetimi, spor ve ulaşım. Tez konularındaki çeşitlilik tezlerde kullanılan anahtar kelimelerine de yansımaktadır. Tablo 4'te en sık kullanılan anahtar kelimeleri gösterilmektedir.

Tablo 4: Siklık Derecesine Göre Anahtar Kelimeler

\begin{tabular}{|l|c|l|c|}
\hline Anahtar Kelimeler & Sıklık & Anahtar Kelimeler & Sıklık \\
\hline Kriz Yönetimi & 67 & Turizm & 4 \\
\hline Kriz & 49 & Afet ve Acil Durum Yönetimi & 3 \\
\hline Otel/Konaklama İşletmeleri & 5 & Aile İşletmeleri/Şirketi & 3 \\
\hline Afet/Doğal Afet & 5 & Afet Yönetimi & 3 \\
\hline Avrupa Birliği & 4 & Bankacılık & 3 \\
\hline Halkla İlişkiler & 4 & Finansal Kriz & 3 \\
\hline Hemşire & 4 & KOBi & 3 \\
\hline Kriz Nedenleri & 4 & Liderlik & 3 \\
\hline Küreselleşme & 4 & Yönetici & 3 \\
\hline Risk & 4 & Yönetim & 3 \\
\hline Sosyal Medya & 4 & & \\
\hline
\end{tabular}

İncelenen tezlerin \% 49'unun anahtar kelimelerine ulaşılmıștır. Tezlerde ifade edilen anahtar kelimeler ilk 2004 yılında yayımlanan bir yüksek lisans tezinde bulgulanmıştır. İlgili tezde beş anahtar kelime kullanılmıştır. Genel olarak tezlerdeki anahtar kelime sayıları farklılık göstermektedir. En az iki ile en fazla on dört anahtar kelimenin ifade edildiği tespit edilmiştir. Toplam 185 farklı kelime kullanılmış ve ortalama kullanılan anahtar kelime sayısı beştir. Kriz yönetimi en sık kullanılan birinci kavram iken, kriz kavramı en sık kullanılan ikinci kavram olmuştur. Kullanılan diğer 183 anahtar kelimesi ise, farklı disiplinlerde çalışılan tez konularındaki çeşitlilik ile yakından ilgilidir. Tablo 4'te ifade edilmeyen anahtar kelimelerinden bazıları şu şekildedir: kriz planı, strateji, kriz iletişimi, deprem, Türkiye, kriz yönetim stratejileri, öğretmen, hastane, örgütsel öğrenme, işletme, kamu yönetimi ve inşaat sektörü. Tablo 5'te tezlerin yazıldıkları enstitüler gösterilmektedir. 
Tablo 5: Tezlerin Yazıldığı Enstitüler

\begin{tabular}{|c|l|c|c|}
\hline Sıra & Enstitü & Yazılan İlk Tez & \% \\
\hline 1. & Sosyal Bilimler Enstitüsü & 1992 & 88 \\
\hline 2. & Fen Bilimleri Enstitüsü & 1998 & 4 \\
\hline 3. & Sağlık Bilimleri Enstitüsü & 2009 & 2 \\
\hline 4. & Eğitim Bilimleri Enstitüsü & 2008 & 2 \\
\hline 5. & Gebze Yüksek Teknoloji Enstitüsü & 1998 & 1 \\
\hline 6. & Avrupa Birliği Enstitüsü & 2005 & 1 \\
\hline 7. & Enformatik Enstitüsü & 2012 & 1 \\
\hline 8. & Stratejik Araştırmalar Enstitüsü & 2013 & 1 \\
\hline
\end{tabular}

Kriz yönetimiyle ilgili tezler açık ara ile sosyal bilimler enstitülerinde ( $\% 88$ ) yazılsa da, Fen Bilimleri Enstitüsü (\% 4), Sağlık Bilimleri Enstitüsü (\% 2), Eğitim Bilimleri Enstitüsü (\% 2), Avrupa Birliği Enstitüsü (\% 1), Enformatik Enstitüsü (\% 1), Gebze Yüksek Teknoloji Enstitüsü (\% 1) ve Stratejik Araștırmalar Enstitüsü (\% 1) gibi farklı enstitülerden de alana katkı sağlanmaktadır. Tezlerde en sık atıf yapılan kitaplar tablo 6'da gösterilmektedir.

Tablo 6: En Sik Atıf Yapılan Kitaplar

\begin{tabular}{|c|l|l|c|c|}
\hline Sıra & Yazar & Kitap & Yıl & Atıf \\
\hline 1. & Dinçer, Ö. & Stratejik Yönetim ve İşletme Politikası & 1998 & 59 \\
\hline 2. & $\begin{array}{l}\text { Can, H.; Azizoğlu, } \\
\text { Ö.A. ve Aydın, E. }\end{array}$ & Organizasyon ve Yönetim & 1997 & 51 \\
\hline 3. & Ataman, G. & İşletme Yönetimi - Temel Kavramlar ve Yeni Yaklaşımlar & 2001 & 39 \\
\hline 4. & Tutar, H. & Kriz ve Stres Ortamında Yönetim & 2000 & 37 \\
\hline 5. & $\begin{array}{l}\text { Pira, A. ve } \\
\text { Sohodol, Ç. }\end{array}$ & Kriz Yönetimi - Halkla İlişkiler Açısından Bir Değerlendirme & 2004 & 30 \\
\hline 6. & Tüz Vergiliel, M. & Kriz Yönetimi & 2004 & 28 \\
\hline 7. & Tüz Vergiliel, M. & Kriz ve İşletme Yönetimi & 2001 & 27 \\
\hline 8. & Kadıbeşegil, S. & Kriz Geliyorum Der & 2003 & 26 \\
\hline 9. & Koçel, T. & $\begin{array}{l}\text { İşletme Yöneticiliği, Yönetim ve Organizasyon, } \\
\text { Organizasyonlarda Davranış, Klasik- } \\
\text { Modern ve Güncel Yaklaşılar }\end{array}$ & 2001 & 25 \\
\hline 10. & Haşit, G. & $\begin{array}{l}\text { İşletmelerde Kriz Yönetimi ve Türkiye'nin Büyük Sanayi } \\
\text { İşletmeleri Üzerinde Yapılan Araştırma Çalışması }\end{array}$ & 2000 & 24 \\
\hline
\end{tabular}

Tezlerde iki ve daha fazla atıf alan kitap sayısı 183'tür. Bu kitapların \% 72'si tek yazarlıdır ve \% 73'ü Türkçe yazılmış kitaplardır (Bu orana Türkçeye çevrilmiş kitaplar dahil edilmemiştir). Tezlerde en sık atıflar 1997-2004 yıllarında yayımlanmış işletme yönetiminde ve temel alandaki Türkçe kitaplarına yapılmıştır. En sık atıf yapılan kitaplar sıralamasında Türk yazarlar ilk 10'da listelenmektedir. Bu listede Ö.Dinçer'in (1998) Stratejik Yönetim ve İşletme Politikası en sık atıf alan kitaptır.

Tezlerde kullanılan yabancı yazarlara ait kitap sayısı 49'dur. Bu kitaplardan 18'i Türkçeye çevrilmiştir. Böylece salt İngilizce dilinde yazılmış kitapların sayısı 31'dir. Çalıșma, alana ilişkin Türkçe literatürün oldukça fazla olduğunu ve yabancı literatüre tercih edildiğini göstermektedir. En sık atıf yapılan Türkçe kitaplar stratejik yönetim ve işletme yönetimi kitapları iken, en sık atıf yapılan yabancı yazarlara ait kitaplar kriz yönetimine ilişkin kitaplardır. 
Tablo 7: En Sik Atıf Yapılan Yabancı Yazarlara Ait Kitaplar

\begin{tabular}{|c|l|l|c|c|}
\hline Sıra & Yazar & Kitap & Yıl & Atıf \\
\hline 1. & Tack, P.B. & Kriz Zamanı Yönetim & 1994 & 22 \\
\hline 2. & Mitroff, I.I. ve Pearson, C.M. & Crisis Management & 1993 & 19 \\
\hline 3. & Luecke, R. & $\begin{array}{l}\text { Kriz Yönetimi: Felaketleri } \\
\text { Önleme Becerinizi Geliştirin }\end{array}$ & 2008 & 17 \\
\hline 4. & Gnesetto, N. (Ed.), & $\begin{array}{l}\text { EU Security and Defence Policy: } \\
\text { The First Five Years (1999-2004) }\end{array}$ & 2004 & 16 \\
\hline 5. & Hammer, M. ve Champy, J. & Değişim Mühendisliği & 1994 & 15 \\
\hline
\end{tabular}

Tablo 7'de en sık atıf alan ve 1993-2008 yıllarında yayımlanmış yabancı yazarlara ait kitaplar gösterilmektedir. Bu kitaplardan üç tanesi Türkçeye çevrilmiştir.

Tablo 8: En Sık Atıf Yapılan Dergilerdeki Çalıșmalar

\begin{tabular}{|c|c|c|c|c|c|}
\hline Sira & Yazar & Dergi Adı & Makale Başığı & YII & Atıf \\
\hline 1. & Baran, $\mathrm{H}$. & $\begin{array}{l}\text { Araştırma ve Meslekleri } \\
\text { Geliştirme Müd. Bülteni }\end{array}$ & İşletmelerde Kriz Yönetimi & 2002 & 24 \\
\hline 2. & $\begin{array}{l}\text { Tağraf, H. ve } \\
\text { Arslan, N.T. }\end{array}$ & $\begin{array}{l}\text { Cumhuriyet Üniversitesi } \\
\text { İktisadî ve İdarî } \\
\text { Bilimler Dergisi }\end{array}$ & $\begin{array}{l}\text { Kriz Oluşum Süreci ve Kriz } \\
\text { Yönetiminde Proaktif Yaklaşım }\end{array}$ & 2003 & 18 \\
\hline 3. & Özdevecioğlu, M. & $\begin{array}{l}\text { Erciyes Üniversitesi } \\
\text { İktisadi ve İdari Bilimler } \\
\text { Fakültesi Dergisi }\end{array}$ & $\begin{array}{l}\text { Krizin İşletmelerin Yönetsel } \\
\text { ve Örgütsel Yapısı Üzerindeki } \\
\text { Olumsuz Etkileri ve Kayseri } \\
\text { Sanayi İşletmelerinde } \\
\text { Yapılan Bir Araştırma }\end{array}$ & 2002 & 17 \\
\hline 4. & $\begin{array}{l}\text { Asunakutlu, } \\
\text { T., Safran, B. } \\
\text { ve Tosun, E. }\end{array}$ & $\begin{array}{l}\text { Dokuz Eylül Üniversitesi, } \\
\text { Sosyal Bilimler } \\
\text { Enstitüsü Dergisi }\end{array}$ & $\begin{array}{l}\text { Kriz Yönetimi Üzerine } \\
\text { Bir Araştırma }\end{array}$ & 2003 & 17 \\
\hline 5. & $\begin{array}{l}\text { Ofluoğlu, G. } \\
\text { ve Mısırlı, K. }\end{array}$ & Kamu İş Dergisi & İşletme ve Kriz Yönetimi & 2001 & 17 \\
\hline 6. & $\begin{array}{l}\text { Murat, G. ve } \\
\text { Mısırlı, K. }\end{array}$ & $\begin{array}{l}\text { Zonguldak Karaelmas } \\
\text { Üniversitesi Sosyal } \\
\text { Bilimler Dergisi }\end{array}$ & $\begin{array}{l}\text { Küçük ve Orta Ölçekli } \\
\text { İşletmelerde Kriz Yönetimi: } \\
\text { Çaycuma Örneği }\end{array}$ & 2005 & 16 \\
\hline 7. & $\begin{array}{l}\text { Titiz, İ. ve } \\
\text { Çarıkçı, H.I. }\end{array}$ & $\begin{array}{l}\text { Cumhuriyet Üniversitesi } \\
\text { İktisadî ve İdarî } \\
\text { Bilimler Dergisi }\end{array}$ & $\begin{array}{l}\text { Krizlerin İşletmeler } \\
\text { Üzerindeki Etkileri }\end{array}$ & 2004 & 15 \\
\hline 8. & Sezgin, F. & $\begin{array}{l}\text { Manas Üniversitesi } \\
\text { Sosyal Bilimler Dergisi }\end{array}$ & $\begin{array}{l}\text { Kriz Yönetimi. } \\
\text { Kırgızistan-Türkiye }\end{array}$ & 2003 & 15 \\
\hline 9. & Tuğcu, Ş.T. & $\begin{array}{l}\text { Selçuk Üniversitesi } \\
\text { İletişim Fak. Dergisi }\end{array}$ & $\begin{array}{l}\text { Kriz Yönetiminde Liderlik } \\
\text { Kavramını Önemi }\end{array}$ & 2004 & 13 \\
\hline 10. & Aykaç, B. & $\begin{array}{l}\text { Gazi Üniversitesi } \\
\text { İktisadi İdari Bilimler } \\
\text { Fakültesi Dergisi }\end{array}$ & $\begin{array}{l}\text { Kamu Yönetiminde Kriz } \\
\text { ve Kriz Yönetimi }\end{array}$ & 2001 & 12 \\
\hline
\end{tabular}

Tezlerde en sık atıf yapılan dergi türleri incelendiğinde, üniversitelerin sosyal bilimleri ve iktisadi idari bilimleri dergileri dikkat çekmektedir. İki ve daha fazla atıf alan makale sayısı 129'dur. Bu makalelerin \% 60'ı tek yazarlıdır, \% 29'u iki yazarlı, \% 9'u üç yazarlı ve \% 2'si dört yazarlıdır. Makalelerin \% 63'ünü (81 makale) Türk yazarların çalışmaları oluşturmaktadır. En sık atıf alan yazarlar sıralamasında da Türk yazarlar ilk 10'da listelenmektedir. Bu listede H. Baran'ın (2002) İşletmelerde Kriz Yönetimi çalışması en sık atıf alan makaledir.

Tablo 6, 7 ve 8'e göre kitaplara yapılan atıflar makalelere yapılan atıflardan daha fazladır; özellikle işletme yönetimine ilişkin Türkçe temel kitaplar, makalelerden ve yabancı literatürden daha fazla atıf almaktadır. 
Tablo 9: En Sik Atıf Yapılan Tezler

\begin{tabular}{|c|l|c|l|c|c|}
\hline Sıra & Yazar & Yıl & Tez Başlığı & Tür & Atıf \\
\hline 1. & Meydan, M. & 2005 & $\begin{array}{l}\text { Kriz Yönetimi ve Muhtemel Bir Krize Karşı } \\
\text { Işletmelerin Hazırlıklarına Yönelik Alan Araştırması } \\
\text { (Denizli Tekstil İşletmeleri Örneği) }\end{array}$ & 13 \\
\hline 2. & $\begin{array}{l}\text { Ataman, G. } \\
\text { (Özbakır) }\end{array}$ & 1992 & İşletmelerde Kriz Yönetimi ve Uygulamadan bir Örnek & YL & 11 \\
\hline 3. & Patan, G.N. & 2009 & İşletmelerde Kriz Yönetimi ve Stratejisinin Önemi & YL & 10 \\
\hline 4. & Akım, F. & 2005 & Liderin/Yöneticinin Kriz Iletişimindeki Rolü ve Önemi & YL & 10 \\
\hline 5. & Tosun, E. & 2002 & $\begin{array}{l}\text { Kriz Durumunda İnsan Kaynakları Yönetimine } \\
\text { Illişkin Stratejiler ve Bir Uygulama }\end{array}$ & YL & 8 \\
\hline 6. & Köroğlu, A. & 2004 & $\begin{array}{l}\text { Turizmde Kriz Yönetimi Otel İşletmelerinde ve } \\
\text { Seyahat Acentalarında Bir Uygulama }\end{array}$ & $\mathrm{D}$ & 8 \\
\hline 7. & Öztürk, A. & 2003 & $\begin{array}{l}\text { Kriz Yönetimi ve Tekstil Sektörüne } \\
\text { Etkileri ile İlgili Bir Uygulama }\end{array}$ & YL & 7 \\
\hline 8. & Demir, Ö. & 2008 & $\begin{array}{l}\text { İşletmelerde Kriz Yönetimi ve Ortadoğu Sanayi ve Ticaret } \\
\text { Merkezindeki (OSTiM) Küçük ve Orta Ölçekli İşletmelerin } \\
\text { Krize Hazır Olma Durumlarına İlişkin Bir Araştırma }\end{array}$ & YL & 7 \\
\hline 9. & Akdağ, M. & 2001 & Halkla Ilişkiler ve Kriz Yönetimi & YL & 7 \\
\hline
\end{tabular}

Tezlerde genel olarak iki ve daha fazla atıf alan tez sayısı 66' dır. 1992-2009 yıllarında yayımlanmıș tezler en çok atıf yapılan tezler olmuștur. Tablo 9'a göre yüksek lisans tezleri, doktora tezlerinden daha fazla atıf almaktadır.

\section{Sonuç}

Yapılan bibliyometrik analiz çalışması ile Türkiye'de kriz yönetimi konusunda yazılan yüksek lisans ve doktora tezlerinin son 25 yıla ilişkin envanteri sunularak alana ilişskin genel eğilimler resmedilmektedir. Böylece kriz yönetimi çalışmalarında öne çıkan yazarlar, en sık kullanılan anahtar kelimeler ile en sık kullanılan kaynaklar ve kaynak türleri, çalışmaların yapıldığı kurumlar ve enstitüler açıklanmaktadır.

Yazılan 161 tezin \% 88'i yüksek lisans ve \% 12'si doktora tezidir. İlk yüksek lisans tezi 1992 yılında Marmara Üniversitesi Yönetim ve Organizasyon Anabilim Dalında ve ilk doktora tezi de 1995 yılında Selçuk Üniversitesi İşletme Bölümünde yazılmıştır. Tezler yıllara göre incelendiğinde büyük dalgalanmalar görülmektedir. 1992-2017 yılları arasında yazılan yüksek lisans tezlerinde süreklilik tespit edilmiş ve en fazla tezin 2010 yılında (19 tez) yazıldığı bulgulanmıştır. Doktora tezlerinde ise küçük bir artış tespit edilse de, hiç yazılmadığı yıllar oldukça fazladır $(1992,1993,1994,1996$, 1997, 1998, 2000, 2001, 2005, 2007, 2011, 2012, 2016).

Yazılan yüksek lisans tezlerinin ortalama sayfa sayısı 148 iken, doktora tezlerinin ortalama sayfa sayısı 285 'dir. Nitekim doktora tezlerinin yüksek lisans tezlerinden iki kat daha fazla sayfa sayısı vardır.

Tezin türüne göre kullanılan kaynak sayıları da değişmektedir. Yüksek lisans tezlerinde kullanılan ortalama kaynak sayısı 70 iken, doktora tezlerinde kullanılan ortalama kaynak sayısı 228'dir. Doktora tezlerinde yüksek lisans tezlerinden üç kat daha fazla kaynak kullanılmaktadır. Yazılan tezlerin \% 94'ü Türkçe ve \% 6'sı İngilizce dilindedir. Hem yüksek lisans hem de doktora tezlerinde erkeklerin oranı kadınlara göre daha fazladır. Bu durum doktora tezlerinde daha da belirgindir (erkekler \% 60; kadınlar \% 40). 
Kriz yönetimiyle ilgili tezler açık ara ile sosyal bilimler enstitülerinde yazılmaktadır. Ancak Fen Bilimleri Enstitüsü, Sağlık Bilimleri Enstitüsü, Eğitim Bilimleri Enstitüsü, Avrupa Birliği Enstitüsü, Enformatik Enstitüsü, Gebze Yüksek Teknoloji Enstitüsü ve Stratejik Araştırmalar Enstitüsü gibi farklı enstitülerden de alana önemli katkılar sağlanmaktadır. Tezler 54 Üniversitede yazılmıștır. En fazla tez Türkiye'nin büyük kentlerindebulunan eski ve köklü devletüniversitelerindeyazılmıştır. Buüniversiteler sırasıyla Marmara Üniversitesi (Kuruluş Tarihi 1883) ve Gazi Üniversitesi'dir (Kuruluş Tarihi 1926). Kriz yönetimiyle ilgili tezlerdeki niceliksel artış, araștırma konularındaki çeşitlilikle paralellik göstermektedir. Tezlerin konuları işletme, kamu yönetimi, halkla ilişkiler, turizm, uluslararası ilişkiler, eğitim, ekonomi, bankacılık ve hemşirelik gibi çok sayıda disipline işaret etse de, işletme konulu tezlerin (\% 40) çokluğu dikkat çekmektedir.

Tez konularındaki bu çeşitlilik tezlerde kullanılan anahtar kelimelerine de yansımaktadır. Tezlerde ifade edilen anahtar kelimeler ilk 2004 yılında yayımlanan bir yüksek lisans tezinde bulgulanmıştır. Genel olarak tezlerde ifade edilen anahtar kelime sayıları farklılık göstermektedir. En az iki ile en fazla on dört anahtar kelimesi ifade edilmiştir. Toplam 185 farklı anahtar kelime kullanılmış ve ortalama kullanılan anahtar kelime sayısı beștir. "Kriz Yönetimi” en sık kullanılan birinci kelime iken, "Kriz" kavramı en sık kullanılan ikinci kelime olmuştur. Kullanılan diğer 183 anahtar kelime ise, farklı disiplinlerde çalışılan tez konularındaki çeşitlilik ile yakından ilgilidir.

Tezlerde iki ve daha fazla atıf alan kitap sayısı 183, makale sayısı 129 ve tez sayısı 66'dır. Atıf alan kitapların \% 72'si tek yazarlıdır ve \% 73'ünü Türkçe yazılmış kitaplar oluşturmaktadır. Tezlerde en sık atıflar 1997-2004 yıllarında yayımlanmış işletme yönetimine ilişkin Türkçe yazılmış kitaplara yapılırken, en sık atıf yapılan makaleler ve dergilerde üniversitelerin sosyal bilimleri ve iktisadi idari bilimleri dergilerinde 2002-2005 yılları arasında yayımlanmış çalışmalar dikkat çekmektedir. Makalelerin \% 63’ünü Türkçe yazılmış çalışmalar oluşturmaktadır. Çalışmaya göre kitaplara yapılan atıflar makalelere yapılan atıflardan daha fazladır. 1992-2009 yılları arasında yazılmış yüksek lisans tezleri en sık atıf yapılan tezler olmuştur.

En sık atıf yapılan kitaplar ve makaleler sıralamasında Türkçe yayınlar ilk 10'da listelenmektedir. Bu listede Dinçer'in (1998) Stratejik Yönetim ve İşletme Politikası en sık atıf alan kitap, Baran'ın (2002) İşletmelerde Kriz Yönetimi başlıklı çalışması en sık atıf alan makaledir. Meydan'ın (2005) Kriz Yönetimi ve Muhtemel Bir Krize Karşı İşletmelerin Hazırlıklarına Yönelik Alan Araştırması başlıklı yüksek lisans tezi ise en sık atıf alan tezdir.

Çalışmada, Türkçe yazılmış kitapların ve makalelerin İngilizce dilinde yazılmış çalışmalardan çok daha fazla atıf alması, Türkçe yazınında kalıcı ve klasik çalışmaların varlığını ve kriz yönetimi literatürüne katkıda bulunan yazarların oldukça fazla olduğunu göstermektedir. Ancak yakın zamanda kriz yönetimiyle ilgili yayımlanmış çalışmalara ilişkin atıflar ve alana ilişkin Conflict and Crises Management, Crisis Management Scholarly Journal, Journal of Contingencies and Crisis Management gibi spesifik dergilerin en çok atıf alan dergiler arasında yer almaması güncel, alana ilişkin ve yabancı literatürün ihmal edildiğini göstermektedir. Oysa Tiryaki'ye $(2014,143)$ göre güncel ve kapsamlı bir literatürle donatılmış bir literatür bölümü, çalışmanın değerini daha da artıran bir olgudur. 
Bulgular, 90’lı yıllardan itibaren hızla büyüyen bir araştırma alanı olarak kriz yönetim araştırmalarında güncel sorunlardaki çeşitliliğin yansıtıldığını göstermektedir. Bundan sonra yapılacak çalışmalarda tezlerin konu başlıkları, literatür bölümünde ifade edilen kuramlar, araştırma bölümünde ifade edilen araştırma soruları ve hipotezleri, araştırma yöntemlerinin niteliği araştırılabilir. Böylece kriz yönetimi literatürüne önemli katkılar sağlanmış olunur.

\section{Notlar}

${ }^{1}$ https://tez.yok.gov.tr/UlusalTezMerkezi/tezSorguSonucYeni.jsp; 31.12.2017

\section{Kaynakça}

Akdağ, M. (2001). Halkla İlişkiler ve Kriz Yönetimi. Yüksek Lisans Tezi. Selçuk Üniversitesi, Sosyal Bilimler Enstitüsü, Konya.

Akgöz, S., Ercan, İ. ve Kan, İ. (2004). Meta-Analizi. Uludağ Üniversitesi Tıp Fakültesi Dergisi, 30(2), 107-112.

Al, U., Sezen, U. ve Soydal, İ. (2012). Hacettepe Üniversitesi Bilimsel Yayınlarının Sosyal A $\breve{g}$ Analizi Yöntemiyle Değerlendirilmesi. Hacettepe Üniversitesi Edebiyat Fakültesi Dergisi, 29(1), 53-71.

Al, U. ve Tonta, Y. (2004). Atıf Analizi: Hacettepe Üniversitesi Kütüphanecilik Bölümü Tezlerinde Atıf Yapılan Kaynaklar. Bilgi Dünyası, 5(1), 19-47.

An, S.K. ve Cheng, I.H. (2010). Crisis Communication Research in Public Relations Journals: Tracking Research Trends over Thirty Years. Timothy Coombs ve Sherry J. Holladay, The Handbook of Crisis Communication. UK: Blackwell Publishing, 65-90.

Baran, H. (2002). İșletmelerde Kriz Yönetimi. Araştırma ve Meslekleri Geliştirme Müdürlüğü Bülteni, 26-32.

Başol, G., Doğuyurt, M. F. ve Demir, S. (2016). Türkiye Örnekleminde Meta Analiz Çalışmalarının İçerik Analizi ve Metodolojik Değerlendirilmesi. International Journal of Human Sciences, 13(1), 714-745. doi:10.14687/ijhs.v13i1.3460

Benckendorff, P. ve Zehrer, A. (2013). A network analysis of tourism research. Annals of Tourism Research, 43, 121-149.

Berelson, B. (1952). Content Analysis in Communication Research. Glencoe: Free Press.

Broom, G. M., Cox, M. S., Krueger, E. A., ve Liebler, C.M. (1989). The gap between professional and research agendas in public relations journals. In J. E. Grunig and L. A. Grunig (Eds.), Public Relations Research Annual, Vol 1, 141-154.

Coombs, T. W. (2016). Reflections on a meta-analysis: Crystallizing thinking about SCCT. Journal of Public Relations Research, Vol. 28(2), 120-122, http://dx.doi.org/10.1080/1062726X.2016.1167479

Coombs, T. W. (2014). Crisis Management and Communications (Updated September 2014). Erişim Tarihi: 02.01.2018, http://www.instituteforpr.org/crisismanagement- communications/

Chen, C. (2006). CiteSpace II: Detecting and visualizing emerging trends and transient patterns in scientific literature. Journal of the American Society for Information Science and Technology, 57(3), 359-377. 
Cutler, A. (2004). Methodical Failure: The Use of Case Study Method by Public Relations Researchers. Public Relations Review, 30(3), 365-375.

Çarkungöz, E. ve Ediz, B. (2009). Meta Analizi. Uludag Univ. J. Fac. Vet. Med., 28,1, 33-37.

Denyer, D. ve Tranfield, D. (2006). Using Qualitative Research Synthesis to Build an Actionable Knowledge Base. Management Decision, 44(2), 213-227.

Dinçer, S. (2014). Eğitim Bilimlerinde Uygulamalı Meta-Analizi. Ankara: Pegem Yayıncilık.

Dinçer, Ö. (1998). Stratejik Yönetim ve İşletme Politikası. İstanbul: Beta Basım Yayım Dağıtım.

Ellegaard, O. ve Wallin, J. A. (2015). The Bibliometric Analysis of Scholarly Production: How Great is the Impact? Scientometrics, 2015; 105(3), 1809- $1831 . \quad$ doi: $10.1007 / \mathrm{s} 11192-015-1645-\mathrm{z}$

Ferguson, M. A. (1984, August). Building theory in public relations: Interorganizational relationships as a public relations paradigm. Paper presented to the Public Relations Division, Association for Education in Journalism and Mass Communication Annual Convention, Gainesville, FL.

Glass, G.V. (1976). Primary, Secondary, and Meta-Analysis of Research. Educational Researcher, 5, 3-8.

Hale, J., Dulek, R. ve Hale, D. (2005). Crisis Response Communication Challenges. Journal of Business Communication, April 2005, 42(2), 112-134.

Halff, G. ve Gregory, A. (2014). Toward an Historically Informed Asian Model of Public Relations. Public Relations Review, 40, (3), 397-407.

https://tez.yok.gov.tr/UlusalTezMerkezi/tezSorguSonucYeni.jsp; Erişim Tarihi: 31.12.2017

Jiang, Y., Brent, W.R. ve Benckendorff, P. (2017). Bibliometric Visualisation: An Application in Tourism Crisis and Disaster Management Research. Current Issues in Tourism, 1-33; https://doi.org/10.1080/13683500.2017.1408574

Khan K.S., Kunz, R., Kleijnen, J. ve Antes, G. (2005). Systematische Übersichten und Meta-Analysen. Ein Handbuch für Ärzte in Klinik und Praxis sowie Experten im Gesundheitswesen. Berlin: Springer Verlag.

Kim, S.Y., Choi, M.; Reber, B.H ve Kim, D. (2014). Tracking Public Relations Scholarship Trends: Using Semantic Network Analysis on PR Journals from 1975 to 2011. Public Relations Review, 40, 116-118.

Kim, S., Avery, E.J. ve Lariscy, R.W. (2009). Are Crisis Communicators Practicing What We Preach? An Evaluation of Crisis Response Strategy Analyzed in Public Relations Research from 1991 to 2009. Public Relations Review, 35(4), 446-8.

Meydan, M. (2005). Kriz Yönetimi ve Muhtemel Bir Krize Karşı İşletmelerin Hazırlıklarına Yönelik Alan Araştırması (Denizli Tekstil İşletmeleri Örneği). Yüksek Lisans Tezi, Afyon Kocatepe Üniversitesi Sosyal Bilimler Enstitüsü, Afyon.

Mitroff, I. I., Shrivastava, P. ve Udwadia, F.E. (1987). Effective Crisis Management. The Academy of Management Executive, 1(4), Nov., 283-292. 
Morton, L. ve Lin, L.Y. (1995). Content and Citation Analyses of Public Relations Review. Public Relations Review, 21, 337-349.

Normand, S.L.T. (1999). Tutorial in Biostatistics Meta-Analysis: Formulating, Evaluating, Combining, and Reporting. Statistics in Medicine, 18(3), 321-359.

Pasadeos, Y., Refro, B. ve Hanily, M.L. (1999). Influential Authors and Works of the Public Relations Scholarly Literature: A Network of Recent Research. Journal of Public Relations Research, 11(1), 29-52.

Pasadeos, Y. ve Renfro, R. B. (1992). A Bibliometric Analysis of Public Relations Research. Journal of Public Relations Research, 4, 167-187.

Price, D.J.S. (1965). Networks of Scientific Papers. Science, 149, 3683, 510-515.

Russo, M.W. (2007). How to Review a Meta-Analysis. Gastroenterol Hepatol (NY), Aug., 3(8), 637-642.

Sallot, L.M., Lyon, L.J., Acosta-Alzuru, C. ve Jones, K.O. (2003). From Aardvark to Zebra: A New Millennium Analysis of Theory Development in Public Relations Academic Journals. Journal of Public Relations Research, 15(1), 27-90.

Soysal, A., Karasoy, H.A. ve Alıcı, S. (2009). KOBİ’lerde Kriz Yönetimi: K. Maraş’ta Tekstil Sektöründeki KOBİlerde Bir Uygulama. Selçuk Üniversitesi Sosyal Bilimler Enstitüsü Dergisi, 21, 431-446.

Stone P.J., Dunphy, D.C., Marshall, S.S. ve Ogilvie, D.M. (1966). The General Inquirer: A Computer Approach to Content Analysis. Massachusetts: The MIT. Press.

Şenyurt, S. ve Özkan, Y.Ö. (2017). Eğitimde Ölçme ve Değerlendirme Alanında Yapılan Yüksek Lisans Tezlerinin Tematik ve Metodolojik Açıdan İncelenmesi. İlköğretim Online, 16(2), 628-653.

Tiryaki, O. (2014). Bilimsel Yayın Hazırlama Teknikleri. ÇOMÜ Ziraat Fakültesi Dergisi, 2(1), 143-155.

Tranfield, D., Denyer, D. ve Smart, P. (2003). Towards a Methodology for Developing Evidenceinformed Management Knowledge by Means of Systematic Review. British Journal of Management, 14, 207-222.

ULAKBIM. (2018). Bibliyometri Nedir? Erişim Tarihi: 11.01.2018, http://cabim. ulakbim.gov.tr/bibliyometrik-analiz/bibliyometrik-analiz-sikca-s o r u l a n sorular/

Wang, Y. ve Dong, C. (2017). Applying Social Media in Crisis Communication: A Quantitative Review of Social Media-Related Crisis Communication Research from 2009 to 2017. International Journal of Crisis Communication, 1, 29-37.

Yıldırım, A. ve Şimşek, H. (2005). Sosyal Bilimlerde Nitel Araştırma Yöntemleri. Ankara: Seçkin Yayıncılık, 8. Basım.

Yıldız, N.G., Melekoglu, M.A. ve Paftalı, A.T. (2016). Türkiye'de Özel Eğitim Araştırmalarının İncelenmesi. Education Online, 2016, 15(4), 1076-1089.

YÖK Tez Merkezi. (2018). Ulusal Tez Merkezi. Erişim Tarihi: 06.12.2018, http:// www.yok.gov.tr/ 
Yuan, Y., Gretzel, U. ve Tseng, Y.H. (2014). Revealing the Nature of Contemporary Tourism Research: Extracting Common Subject Areas Through Bibliographic Coupling. International Journal of Tourism Research, 17(5), 417-431.

Zupic, I. ve Cater, T. (2015). Bibliometric Methods in Management and Organization. Organizational Research Methods, 18(3), 429-472. 